\title{
Loss of fibroblast growth factor 21 action induces insulin resistance, pancreatic islet hyperplasia and dysfunction in mice
}

\author{
WY So ${ }^{1}, Q$ Cheng ${ }^{1}, A X^{2}$, KSL Lam² and PS Leung ${ }^{\star, 1}$
}

Fibroblast growth factor (FGF) 21 is an endocrine factor that normalizes glucose homeostasis and reduces insulin resistance in diabetes. Although the pancreas is an FGF21 target organ, its role in pancreatic islets remains obscure. This study aimed to elucidate the physiological role of FGF21 in pancreatic islets using FGF21-knockout (FGF21-KO) mice. Twenty-four-week-old male global FGF21-KO mice were used in this study. Glucose and insulin tolerance were assessed. Expression of genes and proteins related to islet function and underlying mechanisms were also examined. Islet morphology and insulin-secreting capacity were further evaluated. FGF21-KO mice exhibited insulin resistance while being normoglycemic, associated with increases in beta-cell proliferation and insulin synthesis, acting as compensatory responses. This phenotype probably results from enhanced growth hormone (GH) sensitivity in FGF21-KO mouse islets. In addition, ex vivo FGF21 treatment in normal C57BL/6J mouse islets reduced GH signaling, probably via upregulation of peroxisome proliferator-activated receptor gamma (PPAR $\gamma$ ) and cytokineinducible SH-2 containing (CIS) protein, whereas KO mouse islets displayed reduced PPAR $\gamma$ and CIS expression. FGF21 treatment also reversed GH-induced insulin expression, beta-cell proliferation and GH-impaired glucose-stimulated insulin secretion (GSIS) in islets. Furthermore, distorted islet morphology and impaired GSIS were observed in KO mice, suggestive of islet dysfunction, whereas the enhanced insulin expression and impaired GSIS in FGF21-KO mouse islets could be reversed by blockade of GH signaling. Our data indicate that FGF21 is important in the regulation of beta-cell proliferation and insulin synthesis, probably via modulation of GH signaling. These findings provide evidence that FGF21 is an obligatory metabolic regulator in pancreatic islets and shed new light onto the role of endogenous FGF21 in the pathogenesis of insulin resistance and islet dysfunction.

Cell Death and Disease (2015) 6, e1707; doi:10.1038/cddis.2015.80; published online 26 March 2015

Type 2 diabetes mellitus (T2DM), which is defined as hyperglycemia of sufficient magnitude to lead to detrimental effects, results when insulin resistance develops in association with dysregulated insulin secretion and loss of beta-cell mass. ${ }^{1}$ Insulin resistance prompts pancreatic islet compensatory responses such as increased beta-cell proliferation and insulin production. At this stage, whether an insulin-resistant individual will progress to frank hyperglycemia depends on the ability of islets to provide adequate compensatory insulin secretion. ${ }^{2}$

Fibroblast growth factor (FGF) 21 is an endocrine factor that belongs to the FGF family. It has been demonstrated to be a potent regulator of glycemia, lipid metabolism and energy homeostasis. FGF21 treatment reduces plasma levels of glucose and triglycerides, as well as improves insulin sensitivity and glucose clearance in diabetic mice; FGF21 protects rodents from weight gain and hepatosteatosis upon a high-fat diet challenge ${ }^{3-5}$ FGF21 also improves lipoprotein profiles in nonhuman primates. ${ }^{6}$ Notably, pancreatic islets are one of the major FGF21 targets as FGF21 enhances beta-cell function and survival. ${ }^{7}$ In this context, our laboratory has recently defined the role of FGF21 in islet glucotoxicity under diabetic conditions. ${ }^{8}$

Growth hormone $(\mathrm{GH})$ is synthesized and released by the anterior pituitary gland to regulate multiple physiological processes including growth and metabolism. ${ }^{9,10}$ When GH binds to the GH receptor (GHR) on cell surface, janus kinase 2 (JAK2) is phosphorylated and activated; it in turn phosphorylates members of the signal transducers and activators of transcription proteins (STAT), mainly $5 \mathrm{~A}$ and $5 \mathrm{~B}$, thus leading to their nuclear translocation to regulate target genes transcription. ${ }^{9}$ Several molecules have been identified to modulate GH signaling, including suppressors of cytokine signaling (SOCS), cytokine-inducible $\mathrm{SH}-2$ containing (CIS) protein, ${ }^{11,12}$ and peroxisome proliferator-activated receptor gamma (PPARy), ${ }^{13}$ which directly inhibit phosphorylation or transcriptional activity of JAK and STAT. It is well documented that GH antagonizes insulin action and induces in vitro and

\footnotetext{
${ }^{1}$ School of Biomedical Sciences, Faculty of Medicine, The Chinese University of Hong Kong, Hong Kong, China and ${ }^{2}$ Department of Medicine, Li Ka Shing Faculty of Medicine, University of Hong Kong, Hong Kong, China

${ }^{*}$ Corresponding author: PS Leung, School of Biomedical Sciences, Faculty of Medicine, The Chinese University of Hong Kong, Lo Kwee-Seong Integrated Biomedical Sciences Building, Room 609A, Shatin, Hong Kong, China. Tel: +852 3943 6879; Fax: +852 2603 5123; E-mail: psleung@cuhk.edu.hk

Abbreviations: CIS, cytokine-inducible SH-2 containing protein; ELISA, enzyme-linked immunosorbent assay; FGF, fibroblast growth factor; GAPDH, glyceraldehyde 3-phosphate dehydrogenase; GH, growth hormone; GHR, growth hormone receptor; GSIS, glucose-stimulated insulin secretion; HOMA-IR, homeostasis model assessment of insulin resistance; IPGTT, Intraperitoneal glucose tolerance test; JAK, janus kinases; KO, knockout; KRBB, Krebs-Ringer bicarbonate buffer; PPAR $\gamma$, peroxisome proliferator-activated receptor gamma; RT, reverse transcription; SOCS, suppressor of cytokine signaling; STAT, signal transducers and activators of transcription; T2DM, type 2 diabetes mellitus; WT, wild type

Received 08.12.14; revised 16.2.15; accepted 17.2.15; Edited by A Stephanou
} 
in vivo insulin resistance. ${ }^{10}$ Chronic exposure to $\mathrm{GH}$ modulates insulin signal transduction in muscle and adipose tissues ${ }^{14,15}$ while causing hyperinsulinemia and insulin resistance. ${ }^{16}$ Clinically, humans with acromegaly or with infused $\mathrm{GH}$ exhibit reduced hepatic and extrahepatic insulin actions. ${ }^{17,18}$ On the other hand, it has long been known that GH stimulates beta-cell proliferation and insulin synthesis. ${ }^{19-21}$ Hypersecretion of $\mathrm{GH}$ in rats with $\mathrm{GH}$-secreting tumors results in increased insulin levels with beta-cell proliferation and the development of islet hyperplasia. $^{22,23}$ These findings suggest that $\mathrm{GH}$ acts on beta cells, leading to compensatory responses that cope with the increased insulin resistance.

Meanwhile, recent studies have found that FGF21 interacts with $\mathrm{GH}$; transgenic mice with FGF21 overexpression show reduced growth and blunted hepatic $\mathrm{GH}$ signaling. ${ }^{24}$ Apart from effects on the liver, FGF21 also mediates the chronic undernutrition induction of $\mathrm{GH}$ insensitivity. ${ }^{25}$ Increased FGF21 expression during food restriction directly suppresses growth plate chondrocyte proliferation and differentiation, thus reducing skeletal growth. ${ }^{26}$ Notably, GH can stimulate hepatic FGF21 expression directly or indirectly, suggesting a negative feedback loop that prevents excessive $\mathrm{GH}$ signaling. ${ }^{27,28}$ Although it is known that both FGF21 and GH are involved in the determination of insulin sensitivity and/or resistance, whether FGF21 modulates metabolic parameters via its interaction with $\mathrm{GH}$ has not been investigated. More importantly, it is well recognized that islet dysfunction has a critical role in controlling the progression of T2DM; however, the physiological role of FGF21 and the functional correlate between FGF21 and GH in the islets has not been explored.

In light of these findings and of the knowledge gap identified, this study aimed to elucidate the role of FGF21 in islet function and in the pathogenesis of T2DM and, in particular, to identify the role of $\mathrm{GH}$ signaling via the use of FGF21-knockout (KO) mice.

\section{Results}

FGF21-KO mice are normoglycemic, hyperinsulinemic and insulin resistant. FGF21-KO mice displayed similar overnight fasting blood glucose to values seen in wild-type (WT) mice (Figure 1a; WT $=3.12 \pm 0.25 \mathrm{mmol} / \mathrm{l} ; \mathrm{KO}=3.46 \pm$ $0.34 \mathrm{mmol} / \mathrm{l})$. FGF21-KO mice exhibited slightly higher
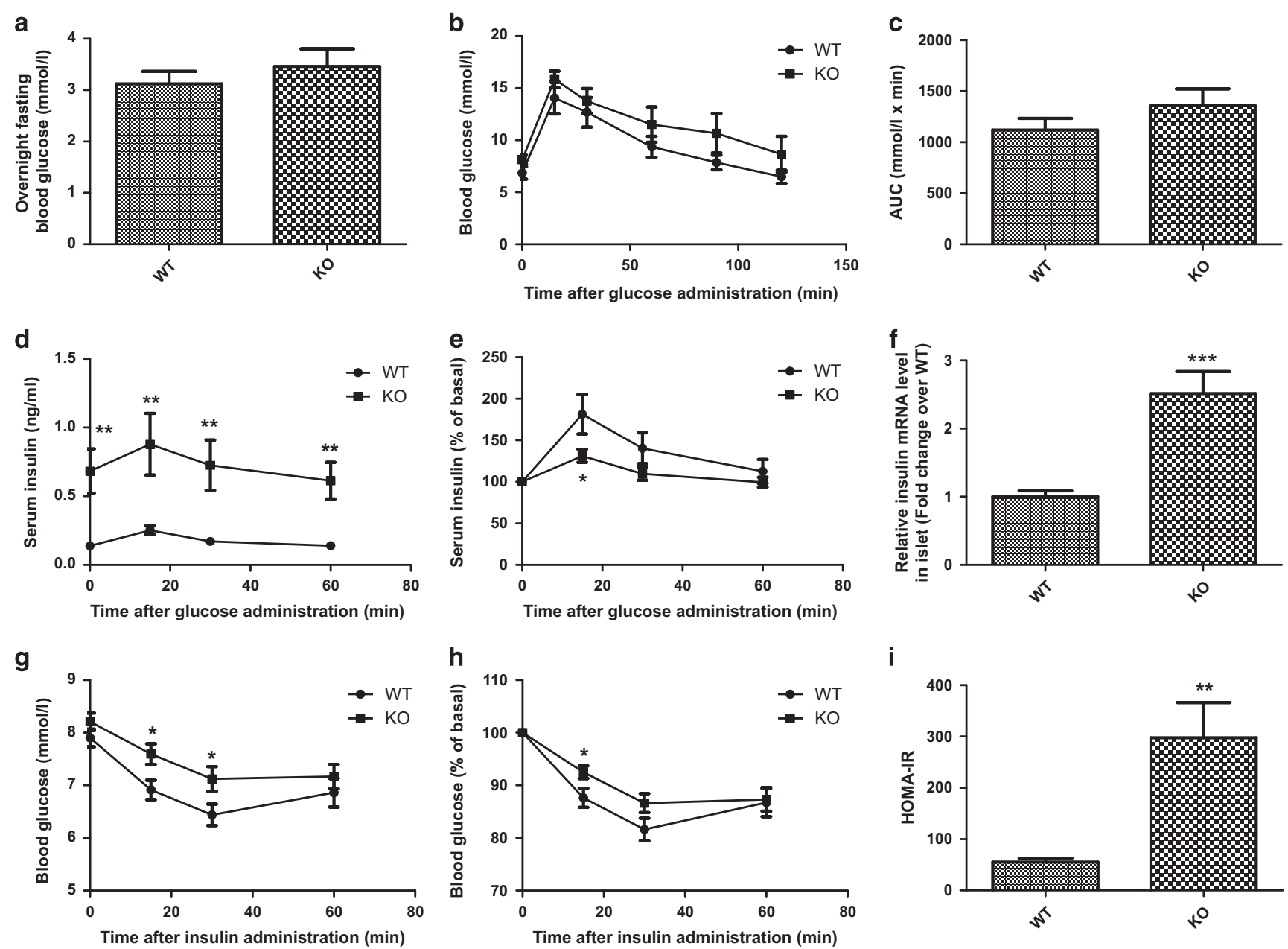

Figure 1 FGF21-KO mice are normoglycemic, hyperinsulinemic and insulin resistant. (a) Overnight fasting blood glucose. (b) Glucose tolerance by IPGTT, and (c) glucose profiles calculated from IPGTT as area under the curve (AUC). Serum insulin levels during IPGTT were expressed as (d) absolute values and (e) \% of basal level. (f) Islet insulin mRNA levels (total RNA was extracted immediately after islet isolation). Blood glucose levels during ITT were expressed as ( $g$ ) absolute values and (h) \% of basal level. (i) Insulin sensitivity was indicated by HOMA-IR. ${ }^{\star} P<0.05,{ }^{* \star} P<0.01$, ${ }^{* *} P<0.001$ versus WT ( $n=4-6$ mice/batch; $4-6$ batches). Data are mean \pm SE 
glucose responses during intraperitoneal glucose tolerance test (IPGTT) to those in WT mice, but these were not significantly different (Figures $1 \mathrm{~b}$ and $\mathrm{c}$; area under the curve: $\mathrm{WT}=1119.84 \pm 112.56 \mathrm{mmol} / \mathrm{I} \times \mathrm{min} ; \mathrm{KO}=1358.51 \pm 164.50$ $\mathrm{mmol} / \mathrm{l} \times \mathrm{min})$. Serum insulin levels of FGF21-KO mice were significantly elevated compared with WT mice during the glucose tolerance test (Figure 1d). However, the response to glucose, expressed as percent of basal insulin, was reduced in $\mathrm{KO}$ mice (Figure 1e). Islet insulin mRNA levels were upregulated in FGF21-KO mice (Figure 1f; 2.5-fold greater than the WT mice). FGF21-KO mice were less insulin sensitive than WT mice with higher blood glucose concentrations at $15 \mathrm{~min}$ and $30 \mathrm{~min}$ after insulin injection (Figures $1 \mathrm{~g}$ and $h$ ) and consistently, the 'homeostasis model assessment' (HOMA-IR) index, which measures the degrees of insulin resistance, was also increased in FGF21-KO mice (Figure 1i).

FGF21-KO mice display islet hyperplasia and increased beta-cell proliferation. FGF21-KO mouse islets were larger than those of WT mice (Figures $2 \mathrm{a}$ and $\mathrm{b}$; WT $=12311.36 \pm$ $\left.884.54 \mu \mathrm{m}^{2} ; \quad \mathrm{KO}=19321 \pm 2290.51 \mu \mathrm{m}^{2}\right)$, as shown by hematoxylin-eosin staining. FGF21-KO mice also had increased beta-cell proliferation (Figure 2c), as evidenced by immunostaining results. In islets from 24-week-old WT mice, the cell proliferation marker Ki-67 was virtually absent, but was easily detectable in FGF21-KO mice. Ki-67 staining was co-localized to the nuclei (labeled by DAPI) of beta cells (stained by insulin), indicating increased beta-cell proliferation (Figure 2d; WT $=0.27 \pm 0.17 ; \mathrm{KO}=0.72 \pm 0.39 \% \mathrm{Ki}-67-$ positive beta cells). A slight, but statistically insignificant increase in islet number per pancreatic section was detected in FGF21-KO mouse islets (Figure 2e; WT $=5.33 \pm 0.80$; $\mathrm{KO}=8.01 \pm 1.08$ islets per section). In addition, FGF21 deficiency did not affect islet apoptosis as shown in Supplementary Figure S1, suggesting that islet hyperplasia in FGF21-KO mice was mainly due to increased beta-cell proliferation.

FGF21-KO mouse islets show distorted morphology and increased alpha-cell population. Immunofluorescent staining of pancreatic islets from FGF21-KO mice revealed a distortion of islet cell distribution. In WT mouse islets, beta cells were located centrally, whereas alpha cells were distributed along the periphery of the islets. Unlike WT mice, some alpha cells in FGF21-KO mouse islets were found in the center of the islets (Figure $3 a$ ). No change was observed a

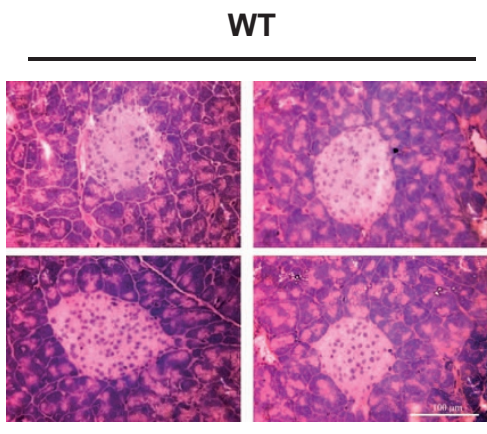

c

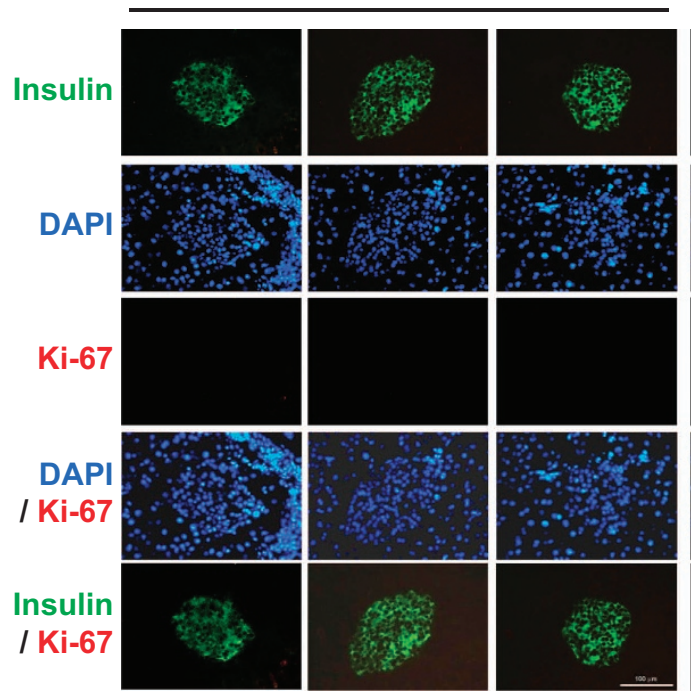

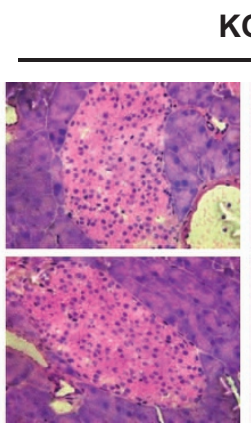

KO

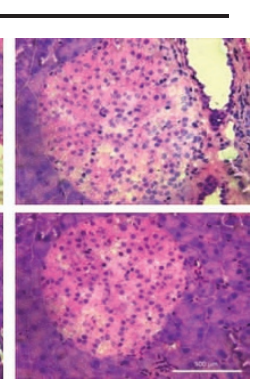

b

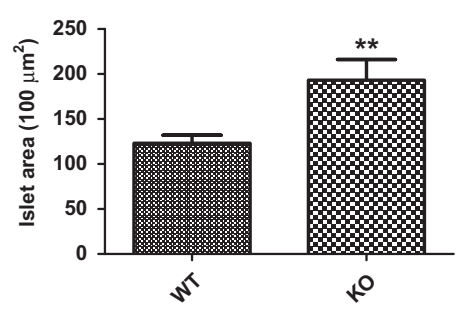

d

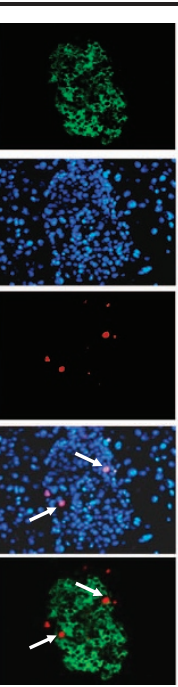

ко

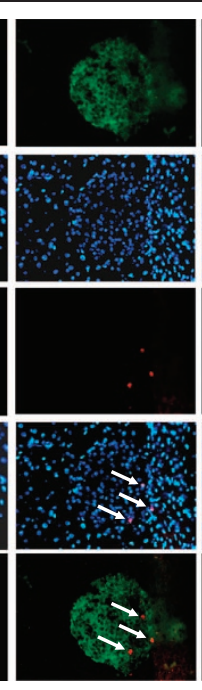

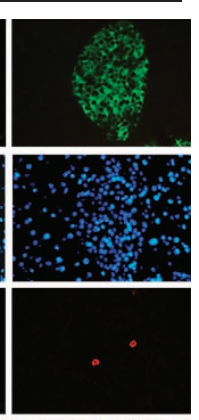

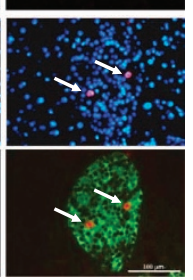

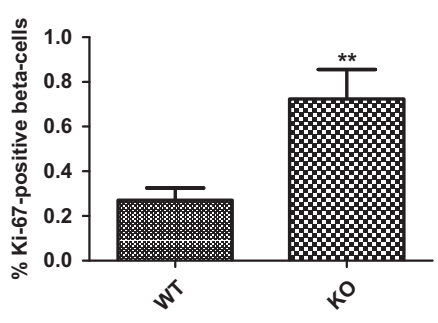

e

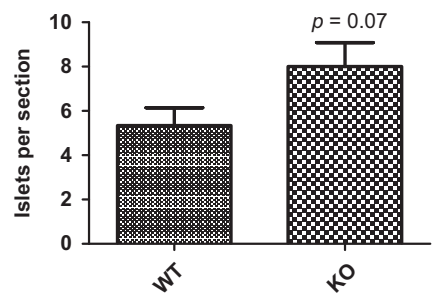

Figure 2 FGF21-KO mice display islet hyperplasia and increased beta-cell proliferation. (a) Representative photomicrographs of islets stained with hematoxylin and eosin, and (b) measurement of islet area. (c) Representative immunostaining of islets labeled for insulin (green), DAPI (blue) and Ki-67 (red). (d) Beta-cell proliferation was analyzed by counting the Ki-67-positive beta-cell number divided by total beta-cell number (\% Ki-67-positive beta cells). (e) Islets per section. Scale bar $=100 \mu \mathrm{m} .{ }^{* \star} P<0.01$ versus WT ( $n=4-6$ mice/batch; three batches). Data are mean \pm SE 
a
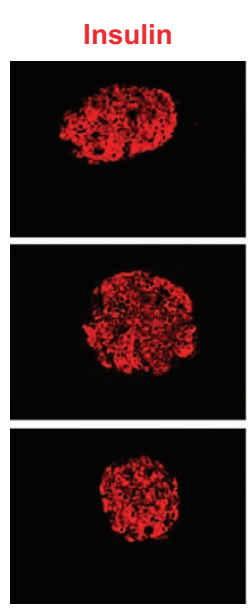

b

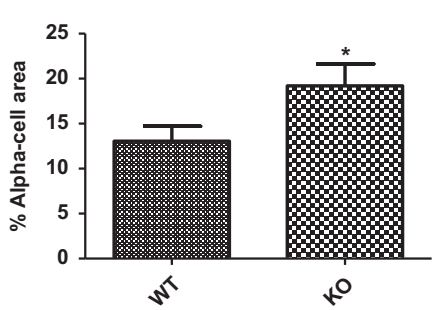

WT
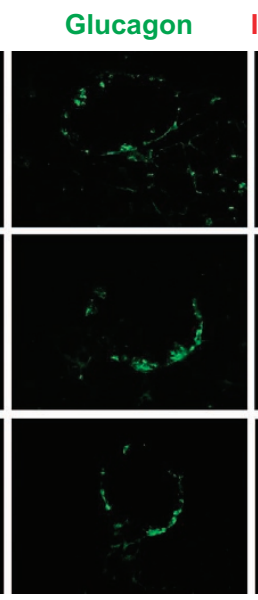

c
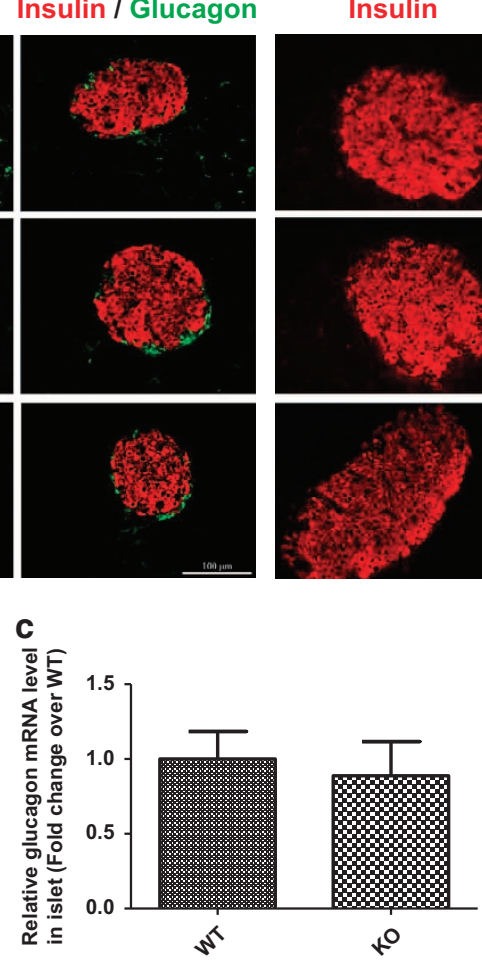

KO
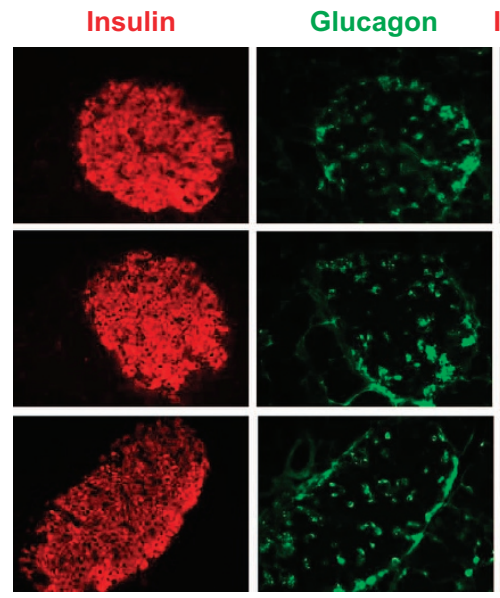

Insulin / Glucagon
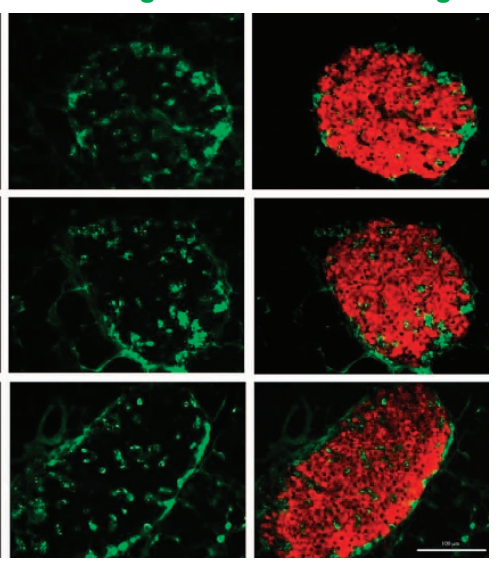

d

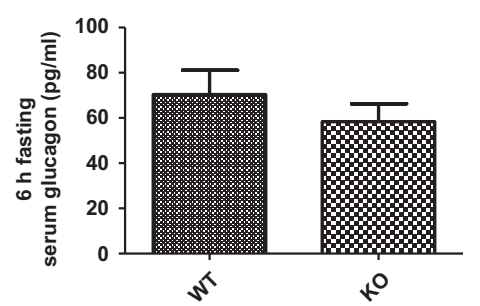

Figure 3 FGF21-KO mice show distorted islet morphology and increased alpha-cell population. (a) Representative photomicrographs of islets labeled for insulin (red) and glucagon (green). Scale bar $=100 \mu \mathrm{m}$. (b) \% of alpha-cell area. (c) Islet mRNA and (d) 6-h fasting serum levels of glucagon. ${ }^{*} P<0.05$ versus WT ( $n=4-6$ mice/batch; four batches). Data are mean \pm SE

in delta-cell distribution as labeled by somatostatin (Supplementary Figure S2). In addition, FGF21-KO mouse islets exhibited an increase in alpha-cell area (Figure $3 b$; $\mathrm{WT}=13.05 \pm 1.67 ; \mathrm{KO}=19.2 \pm 2.43 \%$ alpha-cell area), which is attributed by the increased alpha-cell proliferation as shown by Ki-67 staining (Supplementary Figure S3). However, no significant difference was found in islet mRNA or serum levels (after $6 \mathrm{~h}$ fasting) of glucagon between WT and FGF21-KO mice (Figures 3c and d).

FGF21-KO mouse islets display enhanced GH sensitivity, whereas exogenous FGF21 treatments inhibit GH signaling in normal C57BL/6J mouse islets. To study the crosstalk between FGF21 and GH, serum GH levels in WT and FGF21-KO mice were measured in fed and overnight-fasted states. FGF21 deficiency had no effect on the production of $\mathrm{GH}$ in either fasting or fed state (Supplementary Figure S4A). $\mathrm{GH}$ action in islets was examined by determining GHR expression in both FGF21-KO and WT mouse islets. In 24-week-old mice, GHR mRNA was higher in FGF21-KO than WT mouse islets (Supplementary Figure S4B). However, significant change in GHR protein levels was not detected (Supplementary Figure S4C) while exogenous FGF21 treatment in normal mouse islets did not affect GHR expression (Supplementary Figures S4D and E). Isolated islet responses to $\mathrm{GH}$ were then studied by measuring JAK2 and STAT5 phosphorylation. After treatment with recombinant $\mathrm{GH}(0,25$, 50 , or $100 \mathrm{ng} / \mathrm{ml}$ ) for $15 \mathrm{~min}$, FGF21-KO mouse islets showed enhanced phosphorylation of JAK2 and STAT5 compared with that in WT mouse islets (Figures $4 \mathrm{a}$ and b). To investigate the direct effects of FGF21 on GH action in islets, islets isolated from normal mice were pre-treated with recombinant FGF21 $(0,0.5,1$, or $2 \mu \mathrm{g} / \mathrm{ml})$ before $\mathrm{GH}$-induced signaling was examined. After $72 \mathrm{~h}$ treatment, both JAK2 and STAT5 phosphorylation induced by $\mathrm{GH}(100 \mathrm{ng} / \mathrm{ml})$ was reduced in a dose-dependent manner, in which the greatest effect was found at $2 \mu \mathrm{g} / \mathrm{ml}$ of FGF21 (Figures $4 \mathrm{c}$ and d).

GH-induced insulin expression and beta-cell proliferation are reversed by FGF21 in normal mouse islets. Insulin gene expression and beta-cell proliferation were measured to further examine the effects of FGF21 on $\mathrm{GH}$ actions at the functional levels. As shown in Figure $5 \mathrm{a}, \mathrm{GH}$ treatment $(100 \mathrm{ng} / \mathrm{ml}, 72 \mathrm{~h})$ increased insulin mRNA expression by 2.5-fold in normal mouse islets, whereas co-treatment with FGF21 inhibited GH's effect dose dependently. In addition, GH (100 ng/ml, $72 \mathrm{~h}$ ) increased beta-cell proliferation in normal mouse islets, whereas FGF21 $(2 \mu \mathrm{g} / \mathrm{ml})$ reduced GH's effect (Figures 5b and c; vehicle $=0.25 \pm 0.06 ; \mathrm{GH}=0.93 \pm 0.11 ; \mathrm{GH}$ +FGF21 $=0.48 \pm 0.11 \%$ Ki-67-positive beta cells).

FGF21 inhibits islet GH signaling via modulating the expression of PPARy and CIS. To study the role of PPAR $y$ in the inhibitory effects of FGF21 on GH signaling in islets, PPARy expression was compared between FGF21-KO and WT mouse islets. As shown in Figures $6 a$ and b, PPARy 

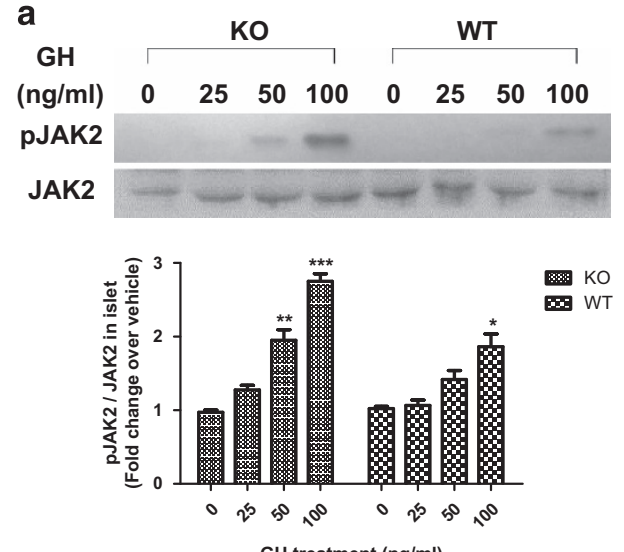

C
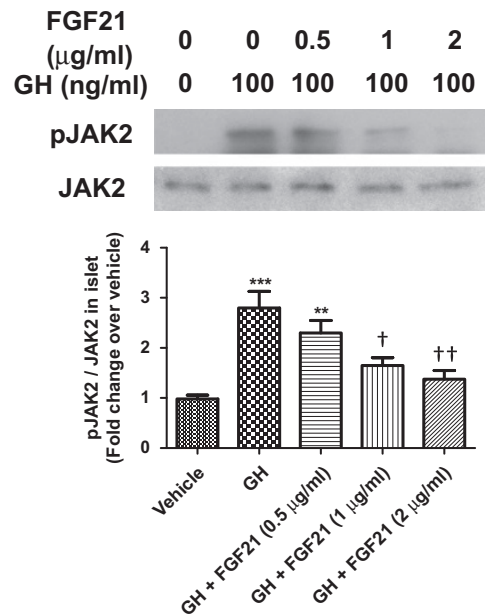

b
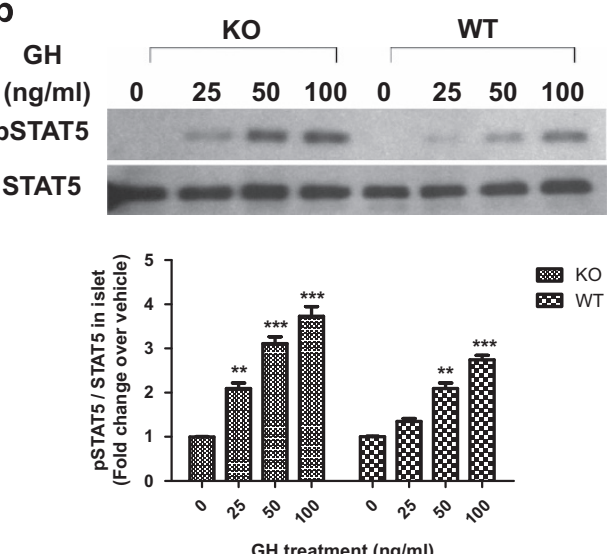

d
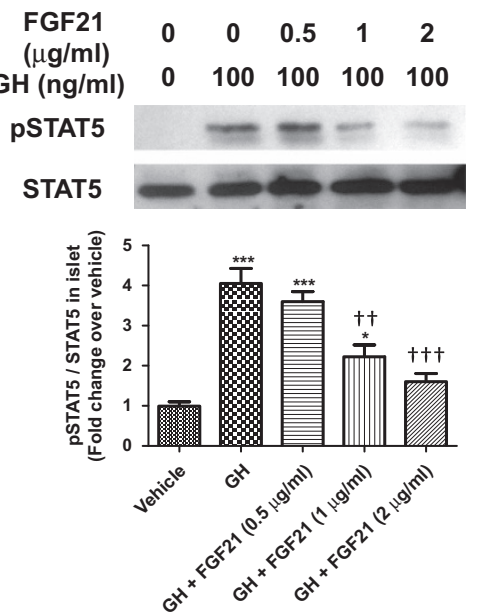

Figure 4 FGF21 inhibits GH signaling in islets. (a) Phosphorylated and total JAK2, and (b) phosphorylated and total STAT5 in FGF21-KO and WT mouse islets treated with GH for 15 min. ${ }^{*} P<0.05,{ }^{* \star} P<0.01,{ }^{* \star *} P<0.001$ versus $0 \mathrm{ng} / \mathrm{ml}(n=3-4)$. (c) Phosphorylated and total JAK2, and (d) phosphorylated and total STAT5 in normal mouse islets pre-treated with FGF21 $(0-2 \mu \mathrm{g} / \mathrm{ml})$ for $72 \mathrm{~h}$, followed by GH $(100 \mathrm{ng} / \mathrm{ml})$ treatment for $15 \mathrm{~min} .{ }^{*} P<0.05,{ }^{*} P<0.01,{ }^{* \star *} P<0.001$ versus Vehicle; ${ }^{\dagger} P<0.05,{ }^{\dagger \dagger} P<0.01$, ${ }^{\mathrm{ttt}} P<0.001$ versus $\mathrm{GH}(n=3)$. Data are mean $\pm \mathrm{SE}$

expression was reduced by $30 \%$ in FGF21-KO mouse islets, whereas FGF21 $(2 \mu \mathrm{g} / \mathrm{ml}, 72 \mathrm{~h})$ increased PPAR $y$ expression in normal mouse islets by $\sim 1.5$-fold. Rosiglitazone $(20 \mu \mathrm{mol} / \mathrm{l})$, a PPARy agonist, did not block GH-induced STAT5 phosphorylation (Figure 6c), but did reverse $\mathrm{GH}$-induced insulin mRNA expression in normal mouse islets (Figure 6d). The role of CIS in FGF21-induced inhibition of $\mathrm{GH}$ signaling was also investigated. Notably, CIS mRNA expression was reduced by $63 \%$ in FGF21-KO mouse islets (Figure 6e), whereas FGF21 increased CIS expression by approximately twofold in normal mouse islets (Figure 6f). In addition, expression of SOCS1 and SOCS3 was unaltered by FGF21 treatment (Supplementary Figures S5A and B), whereas recombinant adiponectin $(1 \mu \mathrm{g} / \mathrm{ml})$ did not affect PPARy expression and $\mathrm{GH}$-induced STAT5 phosphorylation in islets (Supplementary Figures S5C and D), suggesting that these molecules were not involved in FGF21's actions.

FGF21-KO mouse islets exhibit impaired glucosestimulated insulin secretion (GSIS). For islet insulinsecreting capacity, high-glucose challenge induced insulin secretion in both WT and FGF21-KO mouse islets
(Figure 7a). However, the insulin secretion upon glucose challenge was significantly reduced in FGF21-KO mouse islets, as shown by the reduced \% of low glucose (Figure $7 \mathrm{~b}$; $\mathrm{WT}=676.23 \pm 140.4 ; \mathrm{KO}=292.36 \pm 48.66 \%$ of low glucose) . To test whether enhanced GH signaling impairs GSIS in FGF21-KO mice, isolated islets from normal mice were treated with $\mathrm{GH}$, with or without FGF21 prior to GSIS assessment. As shown in Figure 7c, GH (100 ng/ml, $72 \mathrm{~h})$ increased basal insulin secretion (in $1.6 \mathrm{mmol} / \mathrm{l}$ low glucose) as compared with vehicle. Insulin release in response to high glucose was, however, reduced by $\mathrm{GH}$ treatment, but co-treatment with FGF21 $(2 \mu \mathrm{g} / \mathrm{ml})$ reversed the inhibitory effect of GH on GSIS (Figure 7d; Vehicle $=366.78 \pm 63.87$; $\mathrm{GH}=161.76 \pm 18.61 ; \mathrm{GH}+\mathrm{FGF} 21=311.44 \pm 32.29 \%$ of low glucose).

Inhibition of GH signaling in FGF21-KO mouse islets downregulates insulin expression and rescues the impaired GSIS. To further confirm the role of $\mathrm{GH}$ signaling in the phenotypes of FGF21-KO mouse islets, insulin expression and GSIS were measured after inhibition of STAT5. As shown in Figure 8a, inhibition of basal $\mathrm{GH}$ 


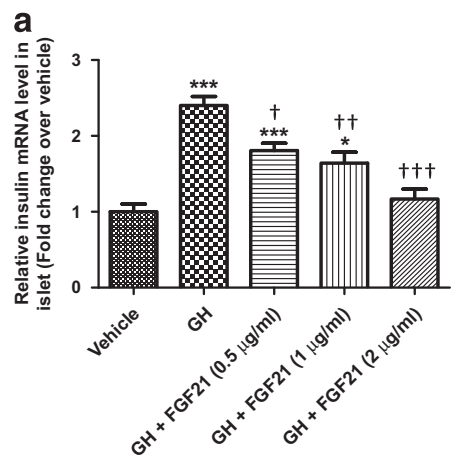

b

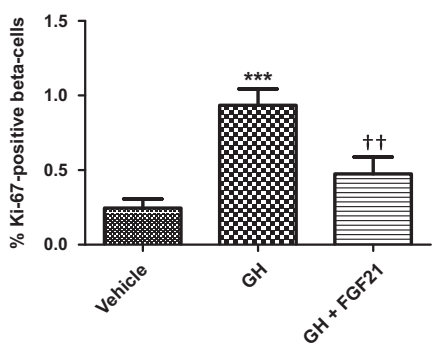

C

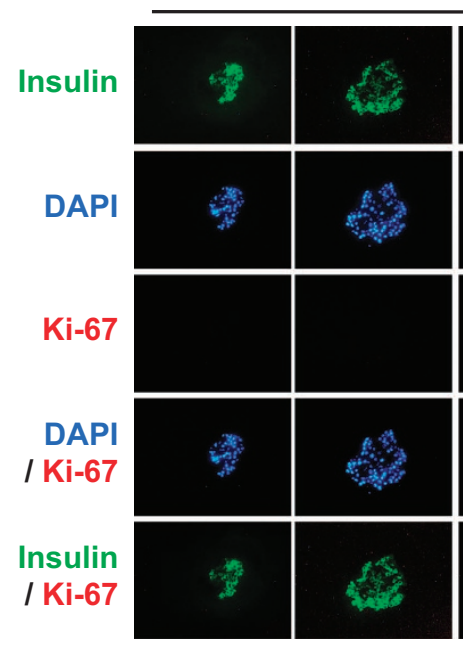

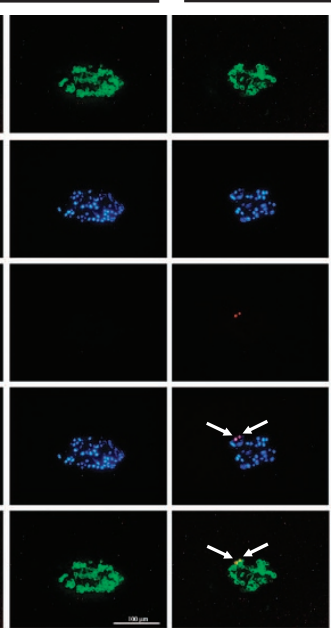

GH

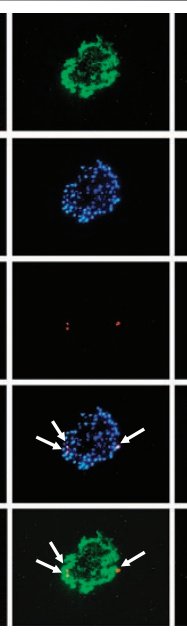

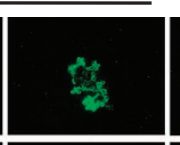

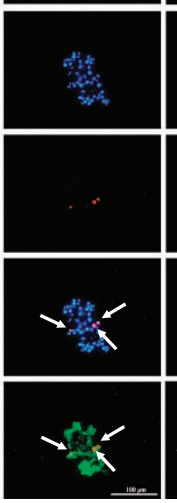

GH + FGF21

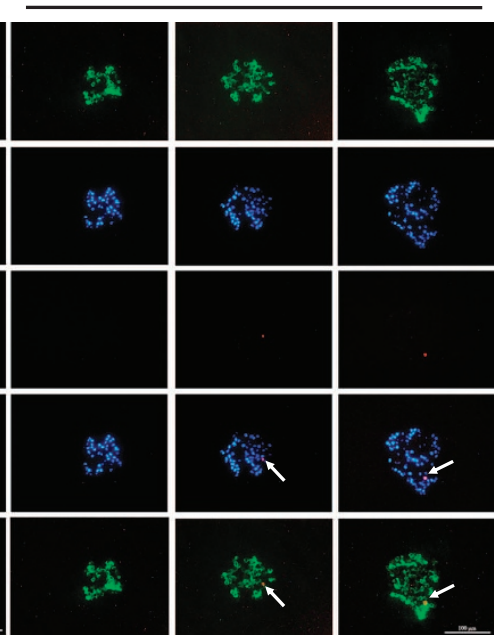

Figure 5 FGF21 reduces GH actions in islets at the functional levels. (a) Insulin mRNA levels in normal mouse islets treated with vehicle, GH (100 ng/ml), and with or without FGF21 $(0.5-2 \mu \mathrm{g} / \mathrm{ml})$ for $72 \mathrm{~h} .{ }^{*} P<0.05,{ }^{* * *} P<0.001$ versus vehicle; ${ }^{\dagger} P<0.05,{ }^{\dagger \dagger} P<0.01,{ }^{t+\dagger} P<0.001$ versus $\mathrm{GH}(n=4)$. (b) Normal mouse islets were treated with vehicle, $\mathrm{GH}(100 \mathrm{ng} / \mathrm{ml})$, and with or without FGF21 $(2 \mu \mathrm{g} / \mathrm{ml})$ for $72 \mathrm{~h}$. Beta-cell proliferation was expressed as $\%$ Ki-67-positive beta cells. ${ }^{* \star *} P<0.001$ versus vehicle; ${ }^{\dagger \dagger} P<0.01$ versus $\mathrm{GH}(n=4)$. (c) Representative immunostaining of islets labeled for insulin (green), DAPI (blue) and Ki-67 (red). Scale bar $=100 \mu \mathrm{m}$. Data are mean \pm SE

signaling in WT mouse islets reduced insulin expression, whereas the increased insulin mRNA level in FGF21-KO mouse islets was almost totally reversed by STAT5 inhibitor $(10 \mu \mathrm{g} / \mathrm{ml}, 72 \mathrm{~h})$. For insulin-secreting ability, STAT5 inhibition did not significantly alter GSIS in WT mouse islets but partially rescued the impaired GSIS in FGF21-KO mouse islets (Figures $8 \mathrm{~b}$ and c; WT $=277.18 \pm 31.00$; WT+STAT\% inhibitor $=257.44 \pm 25.92 ; \quad K O=159.13 \pm 12.80 ; \quad K O+S T A T 5$ inhibitor $=225.05 \pm 17.19 \%$ of low glucose), indicating an improved response to the high-glucose challenge.

\section{Discussion}

The present study is the first to report the modulatory action of FGF21, probably via GH signaling, in the pathogenesis of insulin resistance, and its regulatory role in pancreatic islet response to insulin resistance. FGF21 treatments improve glycemic control, insulin sensitivity and islet function in various animal models. ${ }^{3-7}$ In corroboration, clinical studies have also revealed associations between serum FGF21 levels and parameters of glucose metabolism. ${ }^{29,30}$ However, most previous in vivo studies on FGF21 were based on the gainof-function approaches and whether endogenous FGF21 is an obligatory metabolic regulator remains unclear. In this study, we found that loss of FGF21 in vivo led to increased insulin resistance without changes in glycemia. On the other hand, FGF21 deficiency induced islet hyperplasia and hyperinsulinemia as compensatory responses, which were due, at least in part, to the removal of inhibitory effects of FGF21 on islet GH signaling.

It has been known that glucose is a direct inducer of betacell hyperplasia. ${ }^{31}$ However, in many situations with insulin resistance, both insulin synthesis and beta-cell proliferation are increased without overt changes in glycemia. ${ }^{32}$ Among circulating hormones or growth factors, $\mathrm{GH}$ is well documented as antagonizing the metabolic actions of insulin ${ }^{14,15,33}$ and increasing insulin resistance, ${ }^{17,18}$ as well as being implicated in the islet hyperplasia seen with insulin resistance. ${ }^{32}$ In the current study, we have demonstrated that FGF21 inhibited GH signaling downstream of the GHR through reduction of $\mathrm{GH}$ induced JAK2 and STAT5 phosphorylation, insulin expression, and beta-cell proliferation in pancreatic islets. The loss of FGF21 led to increased islet GH sensitivity without changing circulating $\mathrm{GH}$ levels, as evidenced by enhanced $\mathrm{GH}$-induced JAK2 and STAT5 phosphorylation at the molecular level; this in turn resulted in increased beta-cell proliferation, islet size and insulin production, the well-known effects of GH on islets. ${ }^{19-21}$ Islet cell mass is generally governed by the balance between 
a
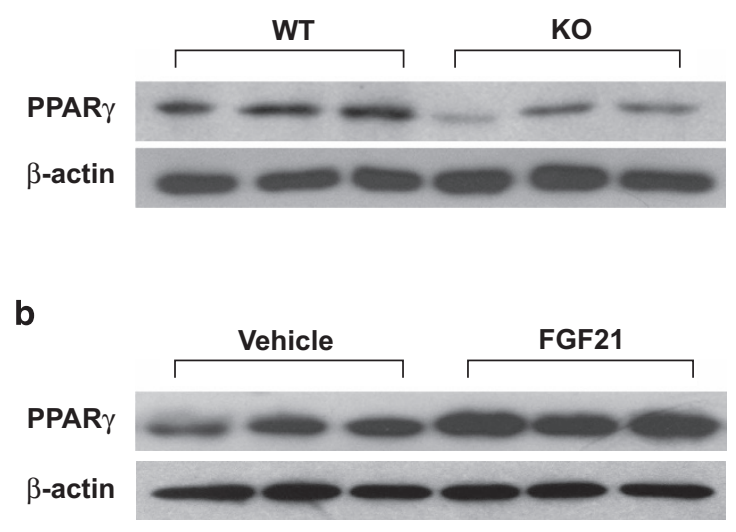

b
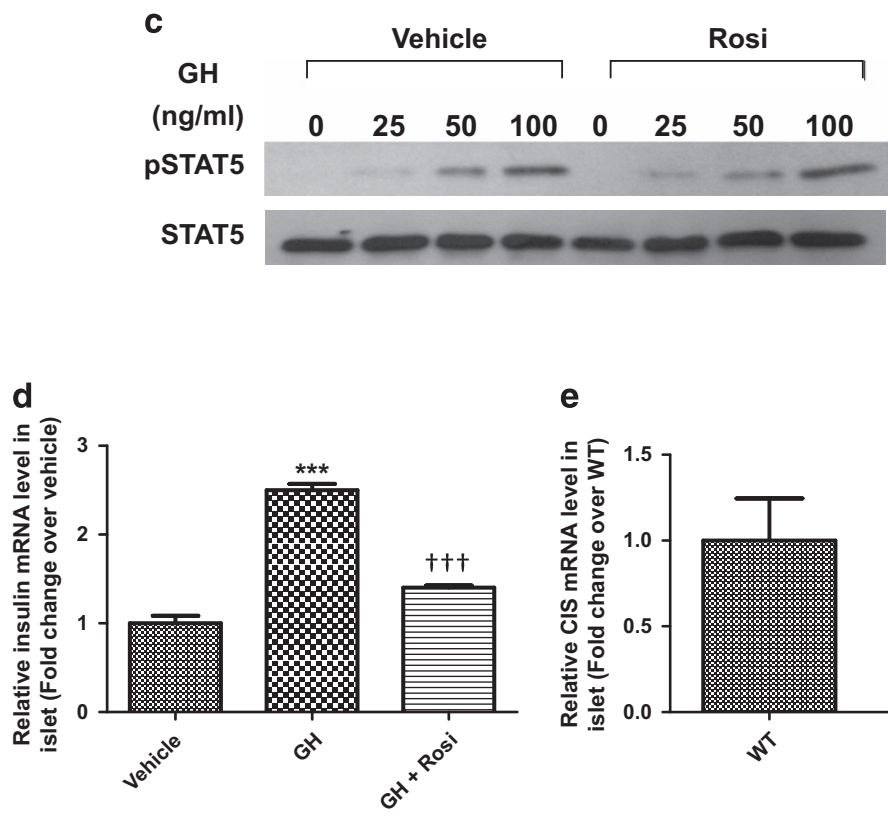

e

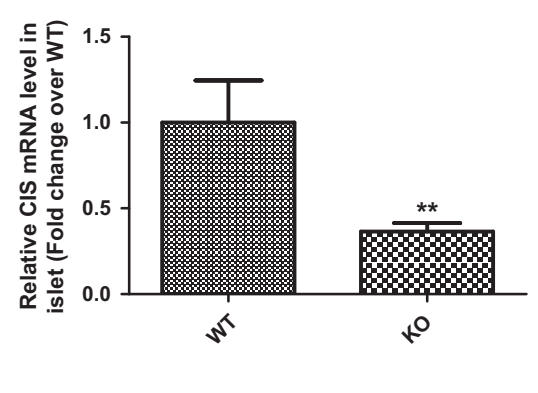

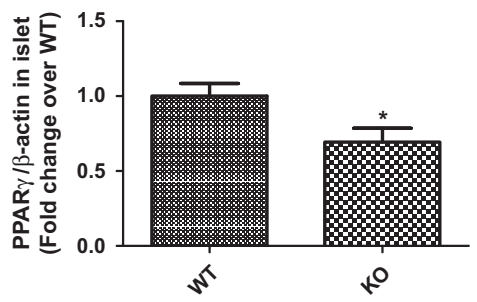
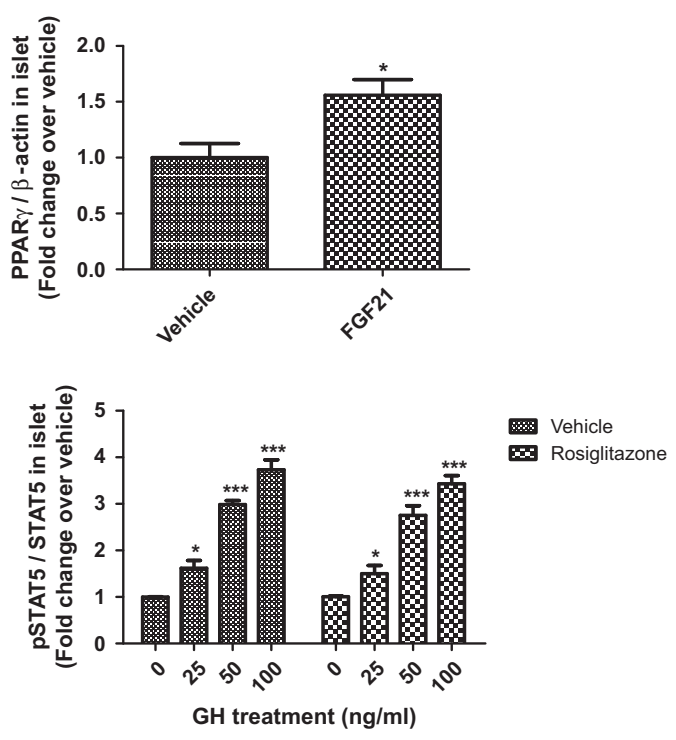

f

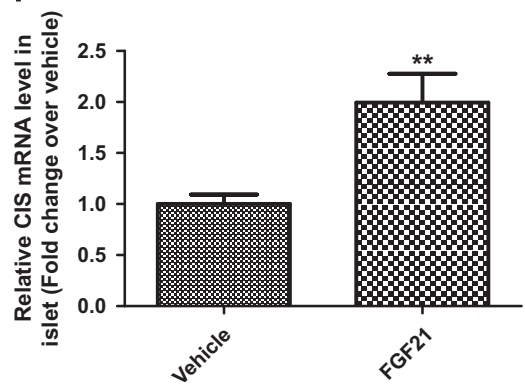

Figure 6 FGF21 inhibits islet GH signaling via induction of PPAR $y$ and CIS expression. (a) Protein levels of PPAR $\gamma$ in FGF21-KO and WT mouse islets. ${ }^{*} P<0.05$ versus WT $(n=3)$. (b) Protein levels of PPAR $\gamma$ in normal mouse islets treated with FGF21 $(2 \mu \mathrm{g} / \mathrm{ml})$ for $72 \mathrm{~h} .{ }^{*} P<0.05$ versus vehicle $(n=3)$. (c) Phosphorylated and total STAT5 in normal mouse islets pre-treated with rosiglitazone (Rosi; $20 \mu \mathrm{mol} / /$ ) for $72 \mathrm{~h}$, then stimulated with $\mathrm{GH}$ for $15 \mathrm{~min}{ }^{*} P<0.05,{ }^{* * *} P<0.001$ versus $0 \mathrm{ng} / \mathrm{ml}(n=3)$. (d) Insulin mRNA levels of normal mouse islets treated with vehicle, $\mathrm{GH}(100 \mathrm{ng} / \mathrm{ml})$ and with or without rosiglitazone (Rosi; $20 \mu$ mol/l) for $72 \mathrm{~h} .{ }^{* * *} P<0.001$ versus vehicle; ${ }^{\dagger+t} P<0.001$ versus $\mathrm{GH}(n=4)$. (e) CIS mRNA levels in FGF21-KO and WT mouse islets. ${ }^{\star \star} P<0.01$ versus WT ( $n=4-6$ mice/batch; three batches). (f) CIS mRNA levels in normal mouse islets treated with FGF21 $(2 \mu \mathrm{g} / \mathrm{ml})$ for $72 \mathrm{~h} .{ }^{*} P<0.01$ versus vehicle $(n=4)$. Data are mean \pm SE

cell proliferation and apoptosis; however, our study has shown no change in islet apoptosis in FGF21-deficient state, suggesting that islet hyperplasia in FGF21-KO mice was largely due to enhanced cell proliferation.

As FGF21 and GH share other target organs, such as the adipose tissue, a major site for insulin, increased insulin resistance under FGF21 deficiency may reflect altered $\mathrm{GH}$ signaling in such organs, whilst concurrent compensatory islet responses would tend to maintain euglycemia in FGF21-KO mice. Several major endocrine tissues (e.g., liver, adipose tissue and pancreatic islets) have been shown to be resistant to FGF21 in obese diabetic mice ${ }^{8,34}$ hence the use of global $\mathrm{KO}$ mice might mimic these in vivo diabetic conditions, when particularly attempting to explore the roles of FGF21 during
T2DM pathogenesis. On the other hand, our ex vivo data have clearly shown that FGF21 directly inhibited GH signaling in isolated islets, as shown by the inhibition on $\mathrm{GH}$-induced JAK2 and STAT5 phosphorylation, as well as $\mathrm{GH}$-induced insulin expression and beta-cell proliferation, which were consistent with the observations in FGF21-KO mice. These data also support our hypothesis that loss of FGF21 would directly regulate islet cell growth and function in vivo. Noticeably, a previous study by Wente et al. ${ }^{7}$ has shown that FGF21 preserves islets and beta cells in $d b / d b$ diabetic mice through reduction of islet glucolipotoxicity and apoptosis, whereas FGF21 does not affect islet cell proliferation. Together with the findings in this study, these results suggest that FGF21 may only inhibit beta-cell expansion induced by excess growth 

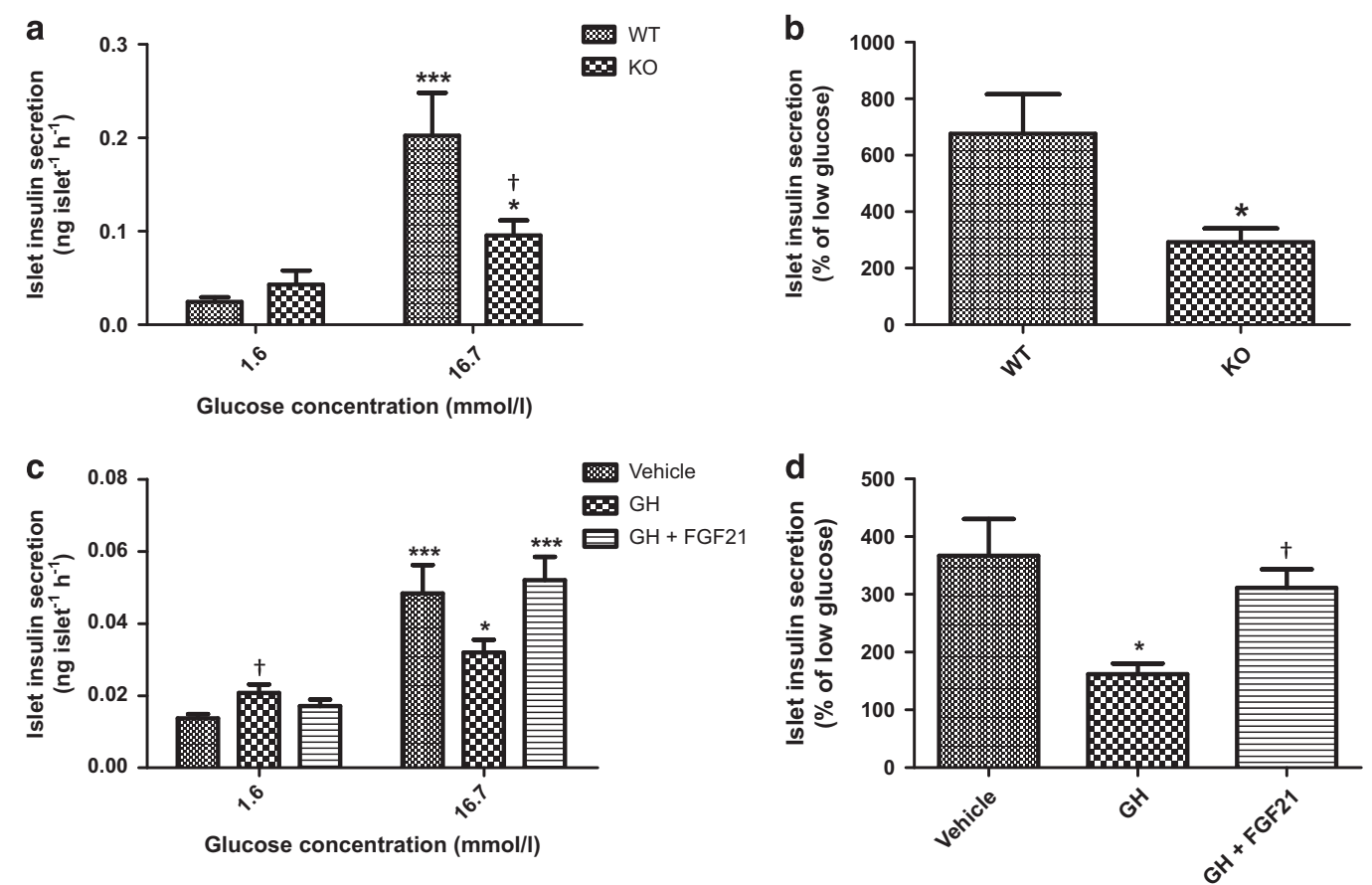

Figure 7 FGF21-KO mice display impaired GSIS. (a) Islet insulin secretion in WT and FGF21-KO mice. ${ }^{*} P<0.05,{ }^{* * *} P<0.001$ versus 1.6 mmol//; ${ }^{\dagger} P<0.05$ versus WT $16.7 \mathrm{mmol} / \mathrm{l}$. (b) Islet insulin secretion was expressed as \% of low glucose. ${ }^{*} P<0.05$ versus WT ( $n=4-6$ mice/batch; four batches). (c) Islet insulin secretion in normal mouse islets pre-treated with GH (100 ng/ml) with or without FGF21 $(2 \mu \mathrm{g} / \mathrm{ml})$ for $72 \mathrm{~h} .{ }^{*} P<0.05,{ }^{* \star} P<0.001$ versus $1.6 \mathrm{mmol} / \mathrm{l} ;{ }^{\dagger} P<0.05$ versus vehicle $1.6 \mathrm{mmol} / /$. (d) Islet insulin secretion was expressed as $\%$ of low glucose. ${ }^{*} P<0.05$ versus vehicle; ${ }^{\dagger} P<0.05$ versus $\mathrm{GH}(n=4)$. Data are mean $\pm \mathrm{SE}$
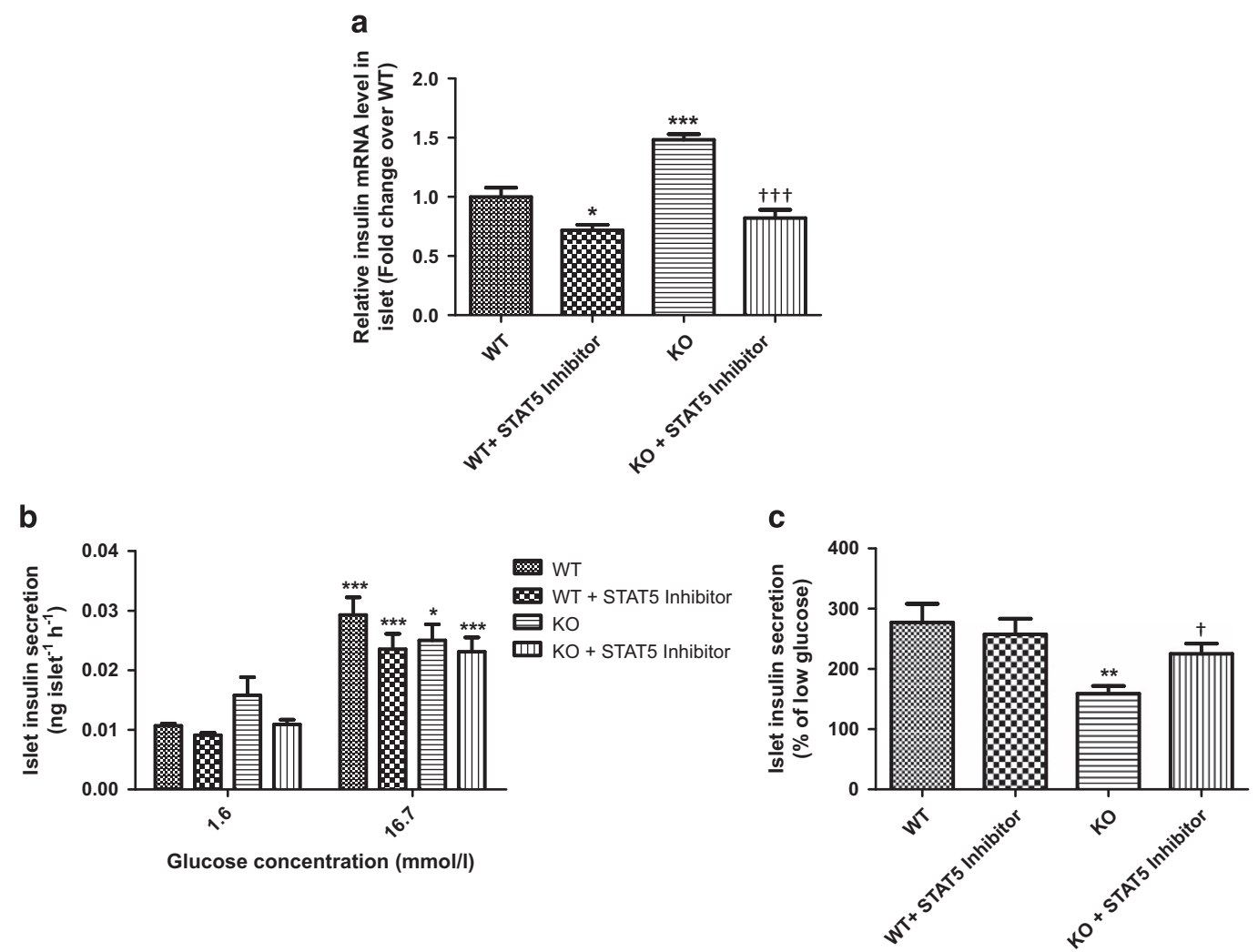

Figure 8 Inhibition of GH signaling rescues the phenotypes of FGF21-KO mouse islets. Isolated islets from WT and KO mice were treated with or without STAT5 inhibitor $(10 \mu \mathrm{g} / \mathrm{ml})$ for $72 \mathrm{~h}$. (a) Islet insulin mRNA levels. ${ }^{*} P<0.05,{ }^{* \star *} P<0.001$ versus WT; ${ }^{\dagger t \dagger} P<0.001$ versus $\mathrm{KO}(n=3)$. (b) Islet insulin secretion. ${ }^{*} P<0.05,{ }^{* \star *} P<0.001$ versus $1.6 \mathrm{mmol} / \mathrm{l}$. (c) Islet insulin secretion was expressed as $\%$ of low glucose. ${ }^{* \star} P<0.01$ versus $\mathrm{WT} ;{ }^{\dagger} P<0.05$ versus KO $(n=4)$. Data are mean $\pm \mathrm{SE}$ 
stimuli, but not in $d b / d b$ mouse islets where most of the beta cells are exhausted. Moreover, systemic administration of FGF21 improves insulin sensitivity and relieves hyperinsulinemia in $o b / o b, d b / d b$ mice, diet-induced obese mice and diabetic monkeys, ${ }^{3-7}$ which are consistent with our data that loss of FGF21 induces insulin resistance and hyperinsulinemia. These findings suggest that FGF21 may act as a positive regulator to maintain normal islet cell mass in different physiological conditions, as well as to maintain normal insulin sensitivity and insulin secretion.

The next issue to address is how FGF21 inhibits islet GH signaling. In this regard, we have shown that FGF21 inhibited $\mathrm{GH}$-induced signaling, probably through the effects on PPARy and $\mathrm{CIS}$, independent of GHR expression. PPARy is a member of the nuclear hormone receptor family, well known to regulate diverse biological processes, including glucose and lipid homeostasis. ${ }^{35}$ Specifically, targeted elimination of PPARy in beta cells is associated with islet hyperplasia, ${ }^{36}$ whereas activated PPARy inhibits GH signaling. ${ }^{13}$ We here report that FGF21 increased islet PPARy expression while PPARy was downregulated in FGF21-deficient islets, which were in line with previous findings that FGF21 promotes PPARy activity and expression in adipose tissue. ${ }^{37,38}$ Rosiglitazone-induced PPAR activation reversed $\mathrm{GH}$ induced islet insulin expression without affecting $\mathrm{GH}$-induced STAT5 phosphorylation, which were consistent with previous work that PPARy inhibits transcriptional activity of STAT5 but not tyrosine phosphorylation. ${ }^{13}$ Therefore, the inhibitory effects of FGF21 on islet JAK2 and STAT5 phosphorylation should be mediated by other pathways. GH signaling is also modulated by SOCS protein and CIS, which specifically inhibit JAK2 and STAT5 phosphorylation. ${ }^{11,12}$ Our findings of reduced CIS mRNA levels in FGF21-KO mouse islets, and the FGF21-induced increase in CIS expression in normal mouse islets, suggest that FGF21 may inhibit GH signaling through the induction of both PPAR $y$ and CIS expression, so that the reduction of PPARy and CIS levels in FGF21-KO mouse islets could lead to enhanced $\mathrm{GH}$ sensitivity. Recent studies have elucidated a regulatory mechanism between FGF21, PPARy and adiponectin in adipose tissue in which adiponectin is a mediator of some specific metabolic actions of FGF21. ${ }^{39,40}$ Our ex vivo studies have demonstrated that direct FGF21 treatments in isolated islets enhanced PPARy expression and reduced $\mathrm{GH}$ signaling. To determine whether adiponectin is involved in the action of FGF21 in islets in vivo, we treated isolated islets with recombinant adiponectin and found that adiponectin did not alter PPAR $y$ expression and $\mathrm{GH}$-induced signaling, suggesting that the effects of FGF21 on islet $\mathrm{GH}$ signaling is independent of adiponectin.

FGF21-KO mice exhibited distorted islet architecture and reduced insulin-secreting capacity during glucose challenge both in vivo and ex vivo, suggestive of islet dysfunction. The molecular mechanism(s) whereby normal spatial distribution of cell types in islets is maintained remains largely unknown. As abnormal islet structure is often accompanied by impaired GSIS, as observed in Glut2-deficient and glucokinasedeficient mice, ${ }^{41,42}$ it is plausible to speculate that abnormal islet architecture itself contributes to impaired GSIS. In addition, FGF21-KO mice displayed increased alpha-cell population even though no difference was found in mRNA or serum levels of glucagon. As $\mathrm{GH}$ does not directly stimulate alpha-cell proliferation, ${ }^{20}$ increased alpha-cell population may be caused by increased insulin, which is known to promote alpha-cell proliferation ${ }^{43}$ but to inhibit both gene transcription and secretion of glucagon. ${ }^{44-46}$ Thus, GH may directly and indirectly increase islet cell population, which contributes to islet hyperplasia in FGF21-KO mice. Dual effects of $\mathrm{GH}$ on islet insulin secretion have been previously reported, with $\mathrm{GH}$ stimulating insulin release directly but inhibiting glucoseinduced insulin release in isolated islets. ${ }^{47}$ In corroboration, our results showed that both $\mathrm{GH}$-treated normal mouse islets and FGF21-KO mouse islets displayed enhanced basal insulin secretion but impaired insulin secretion in response to glucose challenge, which were consistent with the in vivo data that FGF21-KO mice exhibited elevated basal serum insulin but reduced response to glucose administration during the glucose tolerance test. These results demonstrate that enhanced GH sensitivity in FGF21-KO mouse islets altered both basal and stimulated insulin secretion.

In the present study, we found that FGF21 inhibited GH signaling in islets, reversed $\mathrm{GH}$-induced insulin expression, beta-cell proliferation, and impaired GSIS. On the other hand, $\mathrm{GH}$ sensitivity was enhanced in FGF21-KO mouse islets while the increased insulin expression and impaired GSIS could be rescued by blockade of $\mathrm{GH}$ signaling. These data further suggest that those observed phenotypes in FGF21-KO mouse islets are due, at least in part, to the removal of FGF21 inhibition on islet $\mathrm{GH}$ signaling. Our findings thus demonstrate that FGF21 is a critical factor in the maintenance of insulin sensitivity, normal islet cell growth, insulin synthesis, and islet function.

In conclusion, our findings support that FGF21 is an obligatory metabolic regulator in pancreatic islets, which sheds new light into the pathophysiological role of FGF21 in insulin resistance and islet dysfunction.

\section{Materials and Methods}

Animal models. Male FGF21-KO and WT mice of C57BL/6J origin were prepared as we described previously. ${ }^{27,48,49}$ Male normal C57BL/6J mice were obtained from the Laboratory Animal Services Center of the Chinese University of Hong Kong. The experimental procedures were approved by the Animal Experimentation Ethics Committee of the Chinese University of Hong Kong (Ref. No. 12/062/MIS-5).

In vivo glucose homeostasis. Glucose tolerance was assessed by an IPGTT. After $6 \mathrm{~h}$ fasting, mice were given $1.5 \mathrm{~g} / \mathrm{kg}$ body weight of glucose (SigmaAldrich, St. Louis, MO, USA) by intraperitoneal injection and blood glucose was then measured. For the intraperitoneal insulin tolerance test, mice were injected with insulin ( $0.3 \mathrm{U} / \mathrm{kg}$ body weight; Eli Lilly and Company, Indianapolis, IN, USA) after $4 \mathrm{~h}$ fasting, and blood glucose levels were subsequently measured. Degrees of insulin resistance were estimated by HOMA-IR using the following equation: HOMA$\mathbb{R}=$ fasting serum insulin $(\mathrm{mU} / \mathrm{l}) \times$ fasting blood glucose $(\mathrm{mmo} / /) / 22.4$.

Pancreatic islet isolation, primary culture, and treatments. Intact pancreatic islets were isolated from mice as previously described. ${ }^{8}$ Briefly, mouse pancreas was given intra-ductal injection of $0.3 \mathrm{mg} / \mathrm{ml}$ collagenase $P$ (Roche, Mannheim, Germany) in Hanks' balanced salt solution (Sigma-Aldrich). The pancreas was removed and incubated in $37^{\circ} \mathrm{C}$ for $15 \mathrm{~min}$. After washing and gradient centrifugation, the islets were handpicked under a stereomicroscope. Isolated islets were then cultured overnight in RPMI-1640 medium (Life Technologies, Carlsbad, CA, USA) supplemented with 10\% (vol/vol) bovine fetal serum (Gibco, Grand Island, NY, USA), $1 \%$ (vol/vol) penicillin, and streptomycin (Life Technologies). Islets were treated with recombinant FGF21 (University of Hong Kong; HKU, Hong Kong, China), ${ }^{50}$ 
recombinant GH (R\&D Systems, Minneapolis, MN, USA), rosiglitazone (SigmaAldrich) or STAT5 inhibitor (Santa Cruz Biotechnology, Santa Cruz, CA, USA).

Reverse transcription (RT)-PCR. Total RNA from islets was extracted using TRIzol reagent (Life Technologies) and subjected to reverse transcription (RT) using the cDNA Synthesis Kit (Bio-Rad, Munich, Germany). Gene expression was quantified by real-time PCR using SYBR Green Supermix (Bio-Rad) in a Thermal Cycler (Bio-Rad). Relative gene expression was analyzed by the $2^{-\Delta \Delta C t}$ method, and normalized relative to glyceraldehyde 3-phosphate dehydrogenase (GAPDH). ${ }^{8}$ The primer sequences used were as follows: mouse GAPDH forward, $5^{\prime}$-GCACAGT CAAGGCCGAGAAT-3'; mouse GAPDH reverse, 5'-GCCTTCTCCATGGTGGTGAA-3'; mouse insulin forward, 5'-AGCGTGGCTTCTTCTACACAC-3'; mouse insulin reverse, 5'-CTGGTGCAGCACTGATCTACA-3'; mouse GHR forward, 5'-CTTCTCA AGGAAGGGAAGTTG-3'; mouse GHR reverse, 5'-GAATCATCATCCTTTGCTCCA-3'; mouse CIS forward, 5'-CGCAGCGGACAAAAGATTAGG-3'; mouse CIS reverse, 5'-GGACAAGATCCCTGTACGCAA-3'; mouse SOCS1 forward, 5'-CACCTTCTTGG TGCGCG-3'; mouse SOCS1 reverse, 5'-AAGCCATCTTCACGCTGAGC-3'; mouse SOCS3 forward, 5'-GCTCCAAAAGCGAGTACCAGC-3'; mouse SOCS3 reverse, 5'-AGTAGAATCCGCTCTCCTGCAG-3'.

Western blotting. Islet protein was extracted using the CytoBuster Protein Extraction Reagent (Novagen, Darmstadt, Germany). Around 40-50 $\mu \mathrm{g}$ proteins were loaded for each sample. Proteins were separated by SDS-PAGE, transferred to nitrocellulose membrane (Bio-Rad). After blocking, the membrane was probed with antibodies against the following proteins: $\beta$-actin, PPAR $\gamma$ (Santa Cruz Biotechnology), phospho-JAK2 (Y1008), JAK2, phospho-STAT5 (Y694), STAT5 (Cell Signaling, Danvers, MA, USA). After washing, the membrane was probed with appropriate horseradish peroxide-conjugated secondary antibodies. Labeled protein bands were revealed by the ECL detection reagent (GE Healthcare, Piscataway, NJ, USA) on autoradiography films (Fuji Film, Tokyo, Japan). The western blot bands were quantitated with ImageJ software (National Institutes of Health, Bronx, NY, USA).

Measurement of islet insulin release. Fifteen size-matched islets were pre-incubated in Krebs-Ringer bicarbonate buffer (KRBB; supplemented with 10 $\mathrm{mmo} / / \mathrm{HEPES}$ and $2 \mathrm{mg} / \mathrm{ml} \mathrm{BSA}$ ) with $1.6 \mathrm{mmol} / \mathrm{l}$ glucose for $1.5 \mathrm{~h}$ before incubation in KRBB with $1.6 \mathrm{mmol} / \mathrm{l}$ glucose for $1 \mathrm{~h}$, followed by incubation in KRBB containing $16.7 \mathrm{mmol} / \mathrm{l}$ glucose for an additional $1 \mathrm{~h}$, as described previously. ${ }^{51}$ Buffer was collected to measure insulin release by an enzyme-linked immunosorbent assay (ELISA; HKU). ${ }^{39}$

Measurement of serum hormones. Commercial ELISA kits were used to determine serum insulin (HKU) and glucagon (Sigma-Aldrich) according to the manufacturer's instructions.

Pancreatic islet staining. Fresh pancreata or isolated islets were embedded and frozen. Cryostat sections were collected and fixed, as described previously. ${ }^{51}$ For hematoxylin-eosin staining, pancreatic sections were stained with hematoxylin (Sigma-Aldrich) and then counterstained with eosin (Sigma-Aldrich). After washing with water and graded dehydration using ethanol and xylene, slides were mounted with entellan (Merck, Darmstadt, Germany). For immunostaining, slides were incubated with guinea pig anti-insulin (Life Technologies) and rabbit anti-Ki-67 (Abcam, Cambridge, MA, USA) for the detection of beta-cell proliferation and incubated with rabbit anti-insulin (Santa Cruz Biotechnology) and mouse antiglucagon (Abcam) for the assessment of islet morphology. After washing, slides were probed with appropriate fluorescent-conjugated secondary antibodies. After counterstaining with DAPI and washing, slides were mounted with VectaShield medium (Vector-Laboratories, Burlingame, CA, USA) before image acquirement. Digital images were acquired by a fluorescence microscope equipped with a DC200 digital camera (Leica Microsystems, Wetzlar, Germany) and were analyzed by Leica Qwin image analysis software (Leica Microsystems).

Statistical analysis. Data were expressed as means \pm S.E. Comparisons between groups were analyzed by a two-tailed Student's $t$-test, or one-way analysis of variance, followed by Tukey's post hoc test, where $P<0.05$ was considered statistically significant.

\section{Conflict of Interest}

The authors declare no conflict of interest.
Acknowledgements. This work was supported by grants from The Research Grants Council of the Hong Kong Special Administrative Region, China (CRF/ HKU02/12R and GRF/CUHK470413), awarded to PSL. The funders had no role in study design, data collection and analysis, decision to publish, or preparation of the manuscript.

1. Kahn SE. The importance of the beta-cell in the pathogenesis of type 2 diabetes mellitus. Am J Med. 2000; 108: 2S-8S.

2. Kulkarni RN, Kahn CR. Genetic models of insulin resistance: alterations in beta-cell biology In: Habener JF, Hussain M (eds) Molecular Basis of Pancreas Development and Function. Springer: USA, 2001 pp 299-323.

3. Kharitonenkov A, Shiyanova TL, Koester A, Ford AM, Micanovic R, Galbreath EJ et al. FGF-21 as a novel metabolic regulator. J Clin Invest 2005; 115: 1627-1635.

4. Coskun T, Bina HA, Schneider MA, Dunbar JD, Hu CC, Chen Y et al. Fibroblast growth factor 21 corrects obesity in mice. Endocrinology 2008; 149: 6018-6027.

5. Xu J, Lloyd DJ, Hale C, Stanislaus S, Chen M, Sivits G et al. Fibroblast growth factor 21 reverses hepatic steatosis, increases energy expenditure, and improves insulin sensitivity in diet-induced obese mice. Diabetes 2009; 58: 250-259.

6. Kharitonenkov A, Wroblewski VJ, Koester A, Chen YF, Clutinger CK, Tigno XT et al. The metabolic state of diabetic monkeys is regulated by fibroblast growth factor-21. Endocrinology 2007; 148: 774-781.

7. Wente W, Efanov AM, Brenner M, Kharitonenkov A, Koster A, Sandusky GE et al. Fibroblast growth factor-21 improves pancreatic beta-cell function and survival by activation of extracellular signal-regulated kinase $1 / 2$ and Akt signaling pathways. Diabetes 2006; 55 : 2470-2478.

8. So WY, Cheng Q, Chen L, Evans-Molina C, Xu A, Lam KS et al. High glucose represses beta-klotho expression and impairs fibroblast growth factor 21 action in mouse pancreatic islets: involvement of peroxisome proliferator-activated receptor gamma signaling. Diabetes 2013; 62: 3751-3759.

9. Herrington J, Smit LS, Schwartz J, Carter-Su C. The role of STAT proteins in growth hormone signaling. Oncogene 2000; 19: 2585-2597.

10. LeRoith D, Yakar S. Mechanisms of disease: metabolic effects of growth hormone and insulin-like growth factor 1. Nat Clin Pract Endocrinol Metab 2007; 3: 302-310.

11. Ram PA, Waxman DJ. SOCS/CIS protein inhibition of growth hormone-stimulated STAT5 signaling by multiple mechanisms. J Biol Chem 1999; 274: 35553-35561.

12. Hilton DJ, Richardson RT, Alexander WS, Viney EM, Willson TA, Sprigg NS et al. Twenty proteins containing a C-terminal SOCS box form five structural classes. Proc Natl Acad Sci USA 1998; 95: 114-119.

13. Shipley JM, Waxman DJ. Down-regulation of STAT5b transcriptional activity by ligandactivated peroxisome proliferator-activated receptor (PPAR) alpha and PPARgamma. $\mathrm{Mol}$ Pharmacol 2003; 64: 355-364.

14. Thirone AC, Carvalho CR, Brenelli SL, Velloso LA, Saad MJ. Effect of chronic growth hormone treatment on insulin signal transduction in rat tissues. Mol Cell Endocrinol 1997; 130: 33-42.

15. Takano A, Haruta T, Iwata M, Usui I, Uno T, Kawahara J et al. Growth hormone induces cellular insulin resistance by uncoupling phosphatidylinositol 3-kinase and its downstream signals in 3T3-L1 adipocytes. Diabetes 2001; 50: 1891-1900.

16. Cho Y, Ariga M, Uchijima Y, Kimura K, Rho JY, Furuhata $Y$ et al. The novel roles of liver for compensation of insulin resistance in human growth hormone transgenic rats. Endocrinology 2006; 147: 5374-5384.

17. Rizza RA, Mandarino LJ, Gerich JE. Effects of growth hormone on insulin action in man. Mechanisms of insulin resistance, impaired suppression of glucose production, and impaired stimulation of glucose utilization. Diabetes 1982; 31 : 663-669.

18. Hansen I, Tsalikian E, Beaufrere B, Gerich J, Haymond M, Rizza R. Insulin resistance in acromegaly: defects in both hepatic and extrahepatic insulin action. Am J Physiol 1986; 250: E269-E273.

19. Nielsen JH, Svensson C, Galsgaard ED, Moldrup A, Billestrup N. Beta cell proliferation and growth factors. J Mol Med (Berl) 1999; 77: 62-66.

20. Billestrup N, Nielsen $\mathrm{JH}$. The stimulatory effect of growth hormone, prolactin, and placental lactogen on beta-cell proliferation is not mediated by insulin-like growth factor-l. Endocrinology 1991; 129: 883-888.

21. Formby B, Ullrich A, Coussens L, Walker L, Peterson CM. Growth hormone stimulates insulin gene expression in cultured human fetal pancreatic islets. J Clin Endocrinol Metab 1988; 66: 1075-1079.

22. Martin JM, Akerblom HK, Garay G. Insulin secretion in rats with elevated levels of circulating growth hormone due to MtT-W15 tumor. Diabetes 1968; 17: 661-667.

23. Parsons JA, Hartfel MA, Hegre OD, McEvoy RC. Effect of MtTW15 mammosomatotropic tumors on pancreatic islet hormones. Diabetes 1983; 32: 67-74.

24. Inagaki T, Lin VY, Goetz R, Mohammadi M, Mangelsdorf DJ, Kliewer SA. Inhibition of growth hormone signaling by the fasting-induced hormone FGF21. Cell Metab 2008; 8 : 77-83.

25. Kubicky RA, Wu S, Kharitonenkov A, De Luca F. Role of fibroblast growth factor 21 (FGF21) in undernutrition-related attenuation of growth in mice. Endocrinology 2012; 153: 2287-2295. 
26. Wu S, Levenson A, Kharitonenkov A, De Luca F. Fibroblast growth factor 21 (FGF21) inhibits chondrocyte function and growth hormone action directly at the growth plate. J Biol Chem 2012; 287: 26060-26067.

27. Chen W, Hoo RL, Konishi M, Itoh N, Lee PC, Ye HY et al. Growth hormone induces hepatic production of fibroblast growth factor 21 through a mechanism dependent on lipolysis in adipocytes. J Biol Chem 2011; 286: 34559-34566.

28. Yu J, Zhao L, Wang A, Eleswarapu S, Ge X, Chen D et al. Growth hormone stimulates transcription of the fibroblast growth factor 21 gene in the liver through the signal transducer and activator of transcription 5. Endocrinology 2012; 153: 750-758.

29. Chen C, Cheung BM, Tso AW, Wang Y, Law LS, Ong KL et al. High plasma level of fibroblast growth factor 21 is an Independent predictor of type 2 diabetes: a 5.4-year population-based prospective study in Chinese subjects. Diabetes Care 2011; 34: 2113-2115.

30. Xiao Y, Xu A, Law LS, Chen C, Li H, Li X et al. Distinct changes in serum fibroblast growth factor 21 levels in different subtypes of diabetes. J Clin Endocrinol Metab 2012; 97 : E54-E58.

31. Kaung HC. Effect of glucose on beta cell proliferation and population size in organ culture of foetal and neonatal rat pancreases. J Embryol Exp Morphol 1983; 75: 303-312.

32. Araujo TG, Oliveira AG, Saad MJ. Insulin-resistance-associated compensatory mechanisms of pancreatic beta cells: a current opinion. Front Endocrinol (Lausanne) 2013; 4: 146

33. Smith TR, Elmendorf JS, David TS, Turinsky J. Growth hormone-induced insulin resistance: role of the insulin receptor, IRS-1, GLUT-1, and GLUT-4. Am J Physiol 1997; 272: E1071-E1079.

34. Fisher FM, Chui PC, Antonellis PJ, Bina HA, Kharitonenkov A, Flier JS et al. Obesity is a fibroblast growth factor 21 (FGF21)-resistant state. Diabetes 2010; 59: 2781-2789.

35. Rosen ED, Spiegelman BM. PPARgamma: a nuclear regulator of metabolism, differentiation, and cell growth. J Biol Chem 2001; 276: 37731-37734.

36. Rosen ED, Kulkarni RN, Sarraf P, Ozcan U, Okada T, Hsu CH et al. Targeted elimination of peroxisome proliferator-activated receptor gamma in beta cells leads to abnormalities in islet mass without compromising glucose homeostasis. Mol Cell Biol 2003; 23: 7222-7229.

37. Dutchak PA, Katafuchi T, Bookout AL, Choi JH, Yu RT, Mangelsdorf DJ et al. Fibroblast growth factor-21 regulates PPARgamma activity and the antidiabetic actions of thiazolidinediones. Cell 2012; 148: 556-567.

38. Moyers JS, Shiyanova TL, Mehrbod F, Dunbar JD, Noblitt TW, Otto KA et al. Molecular determinants of FGF-21 activity-synergy and cross-talk with PPARgamma signaling. J Cell Physiol 2007; 210: 1-6.

39. Lin Z, Tian H, Lam KS, Lin S, Hoo RC, Konishi M et al. Adiponectin mediates the metabolic effects of FGF21 on glucose homeostasis and insulin sensitivity in mice. Cell Metab 2013; 17: 779-789.

40. Holland WL, Adams AC, Brozinick JT, Bui HH, Miyauchi Y, Kusminski CM et al. An FGF21 adiponectin-ceramide axis controls energy expenditure and insulin action in mice. Cell Metab 2013; 17: 790-797.
41. Guillam MT, Hümmler E, Schaerer E, Yeh JI, Birnbaum MJ, Beermann F et al. Early diabetes and abnormal postnatal pancreatic islet development in mice lacking Glut-2. Nat Genet 1997; 17: $327-330$

42. Terauchi Y, Sakura H, Yasuda K, Iwamoto K, Takahashi N, Ito K et al. Pancreatic beta-cellspecific targeted disruption of glucokinase gene. Diabetes mellitus due to defective insulin secretion to glucose. J Biol Chem 1995; 270: 30253-30256.

43. Liu Z, Kim W, Chen Z, Shin YK, Carlson OD, Fiori JL et al. Insulin and glucagon regulate pancreatic alpha-cell proliferation. PLoS One 2011; 6: e16096.

44. Philippe J. Glucagon gene transcription is negatively regulated by insulin in a hamster islet cell line. J Clin Invest 1989; 84: 672-677.

45. Maruyama H, Hisatomi A, Orci L, Grodsky GM, Unger RH. Insulin within islets is a physiologic glucagon release inhibitor. J Clin Invest 1984; 74: 2296-2299.

46. Kawamori D, Kurpad AJ, Hu J, Liew CW, Shih JL, Ford EL et al. Insulin signaling in alpha cells modulates glucagon secretion in vivo. Cell Metab 2009; 9: 350-361.

47. Kawabe T, Morgan CR. Multiple effects of growth hormone on insulin release from isolated pancreatic islets. Metabolism 1983; 32: 728-731.

48. Liang Q, Zhong L, Zhang J, Wang Y, Bornstein SR, Triggle CR et al. FGF21 maintains glucose homeostasis by mediating the cross talk between liver and brain during prolonged fasting. Diabetes 2014; 63: 4064-4075.

49. Hotta $Y$, Nakamura H, Konishi M, Murata Y, Takagi H, Matsumura S et al. Fibroblast growth factor 21 regulates lipolysis in white adipose tissue but is not required for ketogenesis and triglyceride clearance in liver. Endocrinology 2009; 150: 4625-4633.

50. Ge X, Chen C, Hui X, Wang Y, Lam KS, Xu A. Fibroblast growth factor 21 induces glucose transporter-1 expression through activation of the serum response factor/Ets-like protein-1 in adipocytes. J Biol Chem 2011; 286: 34533-34541.

51. Cheng Q, Boucher BJ, Leung PS. Modulation of hypovitaminosis D-induced islet dysfunction and insulin resistance through direct suppression of the pancreatic islet renin-angiotensin system in mice. Diabetologia 2013; 56: 553-562.

(i) Cell Death and Disease is an open-access journal published by Nature Publishing Group. This work is

licensed under a Creative Commons Attribution 4.0 International

License. The images or other third party material in this article are included in the article's Creative Commons license, unless indicated otherwise in the credit line; if the material is not included under the Creative Commons license, users will need to obtain permission from the license holder to reproduce the material. To view a copy of this license, visit http://creativecommons.org/licenses/by/4.0/ 